\title{
Paradoks bezpieczeństwa w przestrzeni miejskiej
}

\author{
Hubert Trammer \\ Katedra Architektury Urbanistyki i Planowania Przestrzennego, \\ Wydziat Budownictwa i Architektury, Politechnika Lubelska
}

\begin{abstract}
Streszczenie: Przenikanie się ruchu pieszego z kołowym czy tramwajowym daje w wielu przypadkach lepsze efekty pod względem jakości przebywania w mieście, a nawet bezpieczeństwa, niż ich wyraźne oddzielenie od siebie. W niniejszym artykule zostały pokazane przykłady takich rozwiązań.
\end{abstract}

Słowa kluczowe: bezpieczeństwo, przestrzeń miejska, ruch pieszy, ruch samochodowy, ruch tramwajowy, woonerf, strefa zamieszkania, deptak

Przestrzeń bardzo wielu miast, i nie tylko miast, na świecie była w XX wieku, a w bardzo wielu jest nadal przekształcana, w kierunku wprowadzenia daleko idącej segregacji w różnych dziedzinach. Od segregacji funkcji, z osobnym wydzieleniem dzielnic przemysłowych, usługowych, czy mieszkaniowych, po segregację różnych rodzajów ruchu, z często stosowanym oddzieleniem ruchu pieszego od ruchu kołowego poprzez poprowadzenie ich w różnych poziomach. Segregacja w założeniu miała i intuicyjnie może się wydawać, iż powinna przynieść, poprawę warunków życia, w tym poprawę bezpieczeństwa. Często efekty są inne. Monofunkcyjne obszary pustoszeją na znaczną cześć doby i przez brak przebywania w nich ludzi pozbawione są kontroli społecznej [Gehl 2009, Gehl 2014].

Szczególnie interesująco przedstawia się kwestia segregacji ruchu. Przejścia podziemne i prowadzone powyżej poziomu ulic teoretycznie wykluczają możliwość kolizji pomiędzy pieszymi a samochodami. Jednak oddzielenie ruchu pieszego od kołowego w różnych poziomach paradoksalnie, także z punktu widzenia bezpieczeństwa okazują się często rozwiązaniem mniej właściwym, niż układy bardziej kolizyjne. W lutym 2007 roku, w Warszawie, pędzący Aleją Niepodległości samochód wpadł w poślizg, wypadł z jezdni, uderzył w latarnię i następnie wpadł na schody prowadzące do przejścia podziemnego pod ulicą, którą jechał, z którego to przejścia prowadzi też zejście na peron stacji metra Racławicka. Na schodach samochód zabił 81-letniego mężczyznę [mar 2007]. Oczywiście była to sytuacja wyjątkowa i niemająca znaczenia generalnego dla kwestii bezpieczeństwa w przejściach podziemnych. Jednakże pokazuje ona, iż nawet całkowite oddzielenie ruchu pieszego od kołowego poprzez skierowanie ich w różnych poziomach nie daje pełnej gwarancji braku kolizji. Ponadto ten przypadek może być rozpatrywany nie tylko jako spektakularny przykład zaistnienia sytuacji teoretycznie niemożliwej, ale także w szerszym kontekście. Wypadek miał miejsce z powodu brawury kierowcy. Ukształtowanie warszawskiej Alei Niepodległości, z rzadko rozmieszczonymi przejściami dla pieszych, osobnymi dwoma jezdniami, na tym odcinku dodatkowo oddzielonych płotkiem zapobiegającym pokonywaniu ulicy przez pieszych w poziomie terenu, zachęca do szybkiej jazdy. Pędzące samochody zmniejszają bezpieczeństwo na przecinających takie ulice przejściach dla pieszych, a także w wielu przypadkach bezpieczeństwo poruszających się po ulicach bocznych, w które samochody skręcają z większą prędkością niż gdyby wcześniej jechały po ulicy wymuszającej wolniejszy ruch. Znane są przypadki wypadków powodowanych przez kierowców, którzy po zjechaniu z autostrady zredukowali znacząco prędkość, ale nomen omen siłą rozpędu jadą szybciej niż powinni i niż gdyby wcześniej autostradą nie jechali. Ponadto organizacja ruchu oparta na wydzieleniu pieszych od pojazdów w różnych poziomach nie zawsze oznacza, iż są oni faktycznie od siebie oddzieleni. Wielu pieszych zamiast uciążliwego i bardziej czasochłonnego pokonywania poziomów woli poruszać się w poziomie terenu i przekracza jezdnię bezpośrednio, nawet kiedy jest to zakazane. Przejścia nadziemne i podziemne w wielu przypadkach, jako wydzielone przestrzenie, są miejscami kryminogennymi. Sprzyjają temu sytuacje, kiedy tworzą 
one często ciągi o długich odcinkach bez możliwości zmiany trasy przejścia, a jednocześnie pozostające poza kontrolą społeczną, gdy nie ma w ich sąsiedztwie mieszkań ani usług, z których byłyby obserwowane [Czarnecki Siemiński 2004]. Także podziemne przystanki tramwajowe, autobusowe czy stacje metra bywają przestrzeniami kryminogennymi dużo częściej niż przestrzenie publiczne zlokalizowane na powierzchni ziemi.

Rezygnacja z segregacji ruchu, bądź jej istotne ograniczenie daje często efekty sprzeczne z intuicją. Wspólne korzystanie z jednej przestrzeni publicznej pieszych i komunikacji mechanicznej nie musi oznaczać niebezpieczeństwa. W tym miejscu może nasunąć się refleksja, iż skoro wypadek, jaki miał miejsce w 2007 roku w Warszawie, gdzie samochód, który wpadł na schody wiodące do przejścia podziemnego zabił człowieka, został przytoczony jako argument za tym, iż przejścia podziemne nie gwarantują bezpieczeństwa, to tym bardziej argumentem przeciwko łączeniu w jednej przestrzeni ruchu pieszych i pojazdów powinny być zamachy
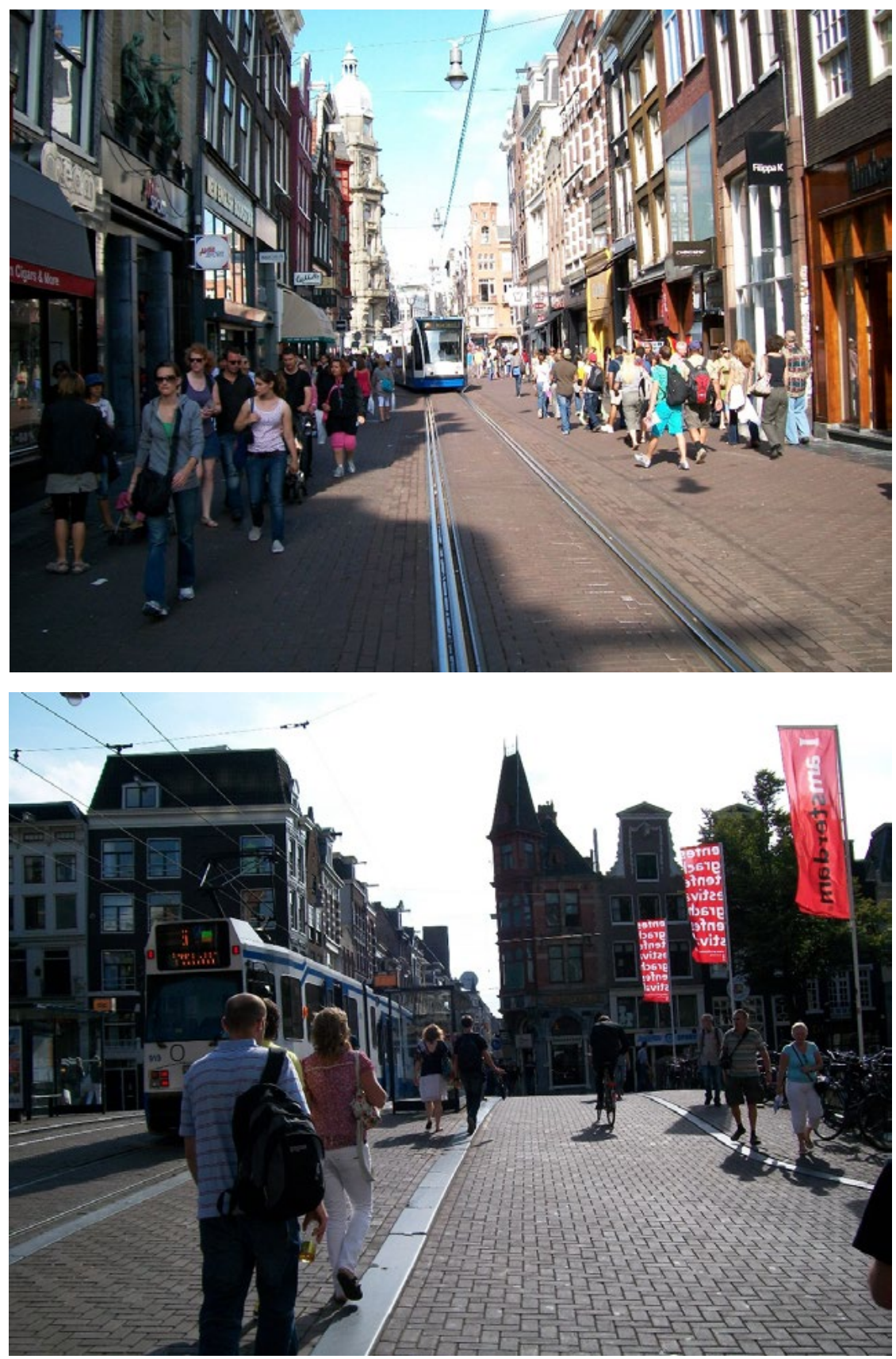

Ryc. 1. i 2. Leidestraat w Amsterdamie. Przestrzeń współistnienia ruchu pieszego z ruchem tramwajowym. U góry odcinek ulicy. $U$ dołu most pomiędzy odcinkami ulicy. Źródło: fot. H. Trammer, 14 sierpnia $2009 \mathrm{r}$.

Leidestraat in Amsterdam. Space of the coexistence of the pedestrian and tram traffic. Top photo: the street between the bridges. Down photo: The bridge between section of the street. Source: phot. Hubert Trammer, August 14 ${ }^{\text {th }}, 2009$. 
terrorystyczne w 2016 roku w Nicei i Berlinie, a wcześniej i później na Bliskim Wschodzie, gdzie ciężarówki wjechały w przestrzenie piesze i zabiły wiele osób. Jednak warto zwrócić uwagę, iż użyte przez terrorystów ciężarówki zabiły pieszych w przestrzeniach przeznaczonych do ich wyłącznego ruchu, a nie do wspólnego ruchu pieszych i pojazdów. Przyglądnijmy się przykładom przestrzeni przeznaczonych dla ruchu pieszego i przebywania w nich ludzi gdzie styk z ruchem pojazdów następuje bez wyraźnego wydzielenia obu rodzajów ruchu. Spektakularnym przykładem jest Leidsestraat (Ryc. 1 i 2) w centrum Amsterdamu. Ulica ta składa się z trzech odcinków przeznaczonych dla ruchu pieszego i tramwajowego poprzedzielanych dwoma mostami na kanałach gdzie dodatkowo odbywa się ruch samochodowy i rowerowy. Mosty są szersze niż odcinki ulicy zlokalizowane pomiędzy nimi. Na mostach umieszczono po dwa tory tramwajowe, po dwa perony przystanków tramwajowych będące zarazem chodnikami, po dwie jezdnie dla samochodów umożliwiające przejazd między ulicami
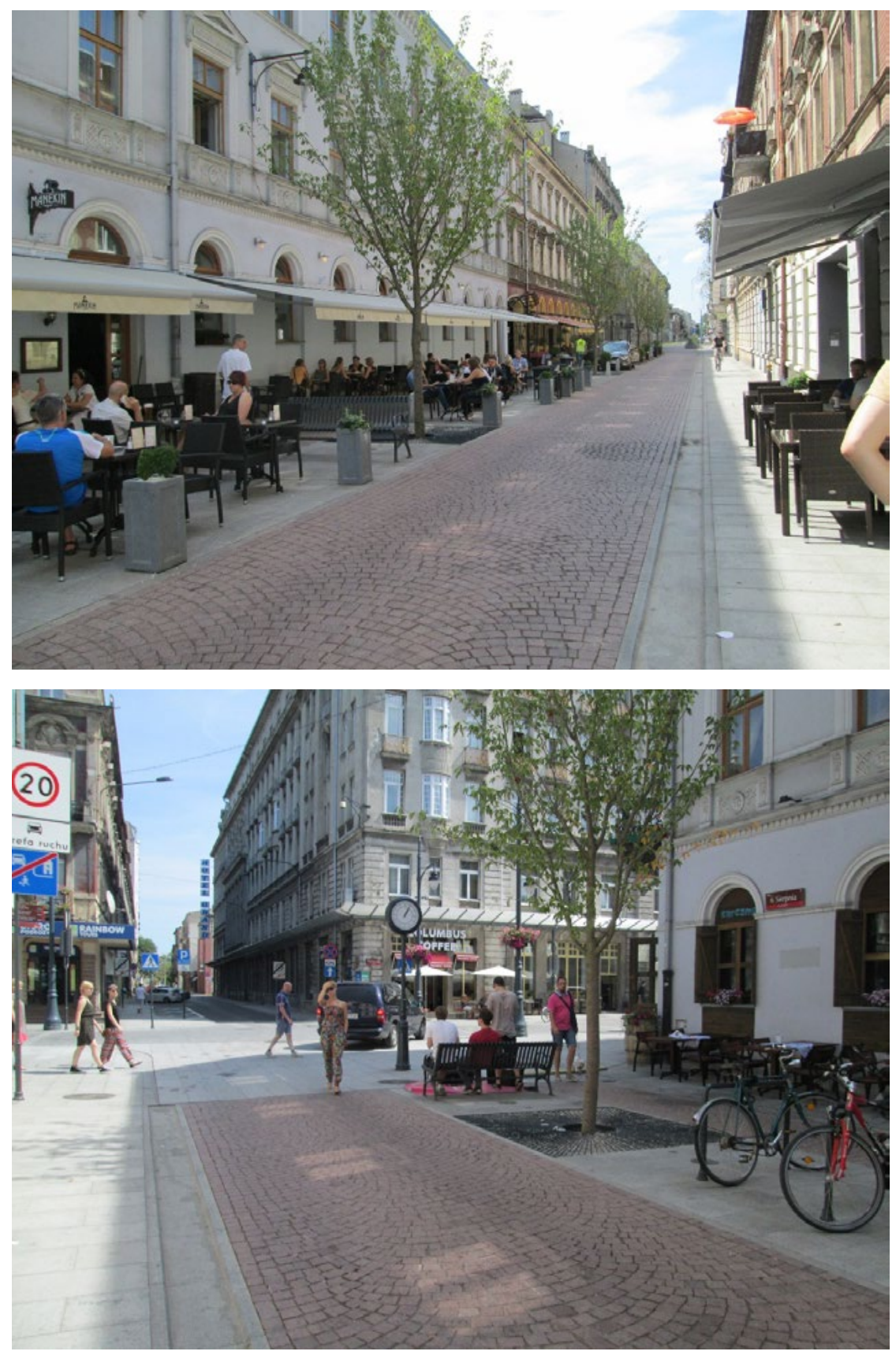

Ryc. 3. i 4. Ulica 6 Sierpnia w Łodzi, której przekształcenie w woneerf dało początek popularności tego rozwiązania w Polsce. Źródło: fot. H. Trammer, 10 sierpnia $2014 \mathrm{r}$.

Sierpnia Street in Łódź. Transformation of it into living street started popularity of that solution in Poland. Source: phot. Hubert Trammer, August the $10^{\text {st }}, 2014$ 
biegnącymi po obu stronach kanałów, a także po dwa chodniki umieszczone przy balustradach mostu. Umieszczone na mostach przystanki odgrywają także rolę mijanek. Bowiem na wąskiej Leidestraat zastosowano tak zwane sploty torów, czyli nałożenie na siebie szerokości obu torów, zawężające przestrzeń poruszania się tramwajów. Po trasie biegnącej przez Leidestraat kursują trzy linie tramwajowe mające łączną szczytową częstotliwość co dwie minuty w każdym z obu kierunków. Na szerokości ulicy mniejszej niż dziesięć metrów ruch pieszy współistnieje z tramwajowym. Nie są oddzielone od siebie żadnymi fizycznymi barierami. Sytuacje współistnienia ruchu tramwajowego z pieszym w jednej przestrzeni funkcjonują także wielu innych miastach. W tym polskich. Na przykład w Chorzowie, Gorzowie Wielkopolskim i Wrocławiu. Przykład Leidestraat w Amsterdamie jest szczególnie spektakularny ze względu na bardzo małą szerokość ulicy, bardzo intensywny ruch pieszy i dwukierunkowy ruch tramwajowy o dużej częstotliwości prowadzony po torach ze splotami, a więc z koniecznością dużej dbałości o jego regularność.
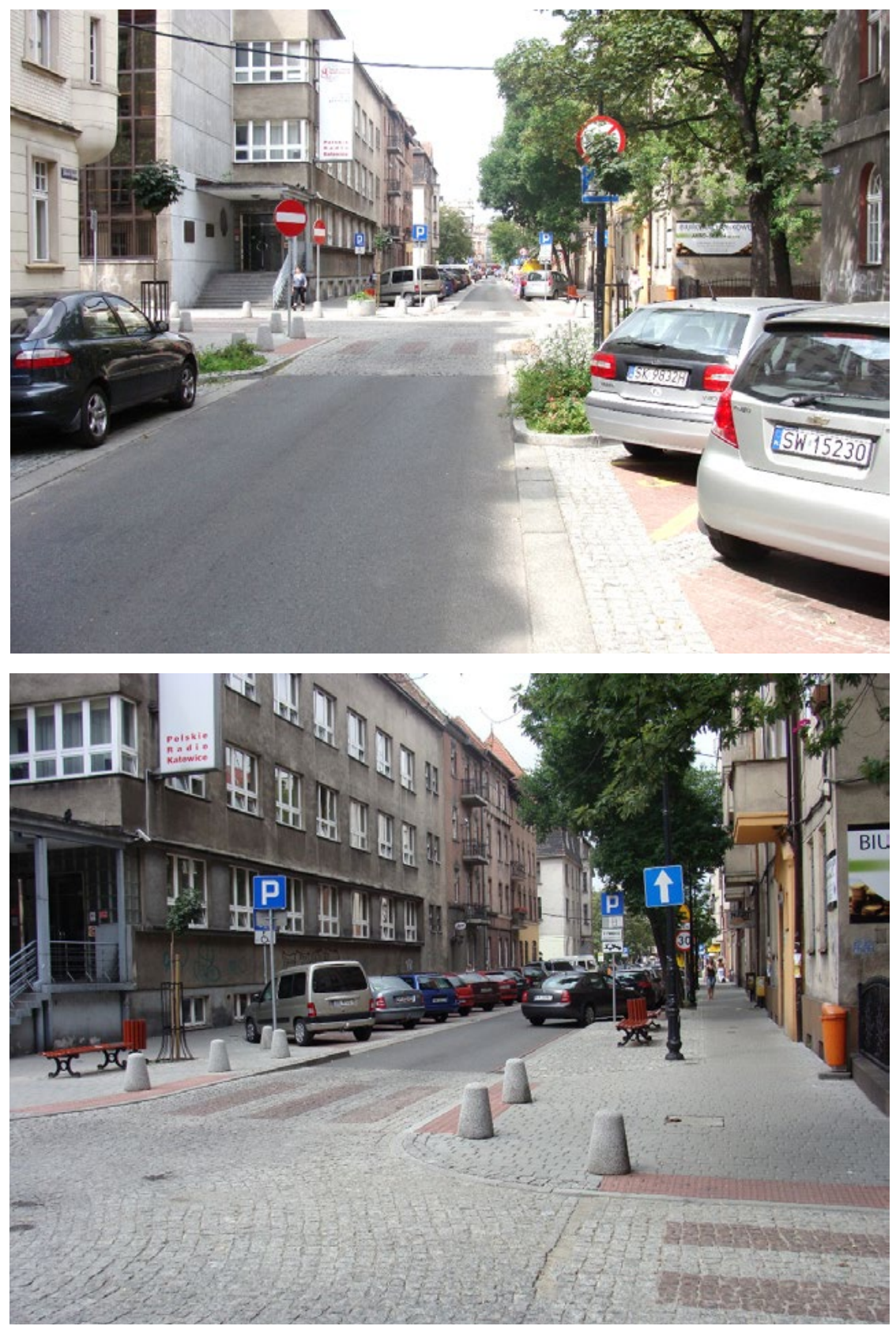

Ryc. 5. i 6. Wyniesione do poziomu chodników i wyróżnione nawierzchnią skrzyżowanie ulic Juliusza Ligonia i Królowej Jadwigi w centrum Katowic. Źródło: fot. H. Trammer, 3 sierpnia $2009 \mathrm{r}$.

Crossroad of the Juliusza Ligonia and Królowej Jadwigi streets in the center of Katowice. The surface of the crossroad is elevated to the level of the pavements and marked by the paving. Source: phot. Hubert Trammer, August the $3^{\text {rd }}, 2014$. 
Kojarzonym z Holandią sposobem organizacji ruchu opartym na współistnieniu ruchu pieszego z samochodowym są tak zwane woonerfy. Rozwiązanie to zyskało popularność w Polsce dzięki spektakularnemu sukcesowi przebudowy ulicy 6 sierpnia z Łodzi (Ryc. 3 i 4). Wcześniej, kiedy przestrzeń tej ulicy była podzielona na jezdnię i wąskich chodnikach, ludzie niechętnie tam przebywali. Po przebudowie na woonerf stała się pełnym życia fragmentem miasta. Mimo przenikania się ruchu pieszego z samochodowym, a może dzięki temu nie ma problemów z bezpieczeństwem [Kubecka Zimny 2016]. W odróżnieniu od wielu woonerfów występuje tam nie tylko ruch lokalny, ale także tranzytowy. Holenderskie słowo woonerf oznacza strefę zamieszkania. Tymczasem w Łodzi i w innych miejscach w Polsce określenie to stosowane jest do śródmiejskich przestrzeni stricte publicznych.

W relacji pomiędzy ruchem pieszym, a innymi rodzajami ruchu istotne jest ich współistnienie w miejscach gdzie dla zapewnienia ciągłości każdego z nich nakładają się na siebie powierzchnie przeznaczone dla ich prowadzenia w oddzieleniu. Różny sposób ich rozwiązania tworzy różne relacje pomiędzy poszczególnymi rodzajami ruchu. Zwykle są to miejsca przechodzenia pomiędzy przeznaczonymi do ruchu pieszych chodnikami przez przeznaczoną do ruchu pojazdów jezdnię. Przy najczęściej występujących w Polsce sposobach organizacji ruchu najczęściej występują trzy rodzaje takich miejsc. Pierwszy to powierzchnie bez specjalnego wyznaczenia, gdzie można przechodzić przez jezdnię na zasadzie ogólnych przepisów, a więc obręb skrzyżowań i odcinki ulic położone ponad 100 metrów od skrzyżowań i wyznaczonych przejść dla pieszych, pozbawione cech, które sprawiają, iż przepisy nie pozwalają tam przechodzić przez jezdnie. W takich miejscach zgodnie z przepisami,
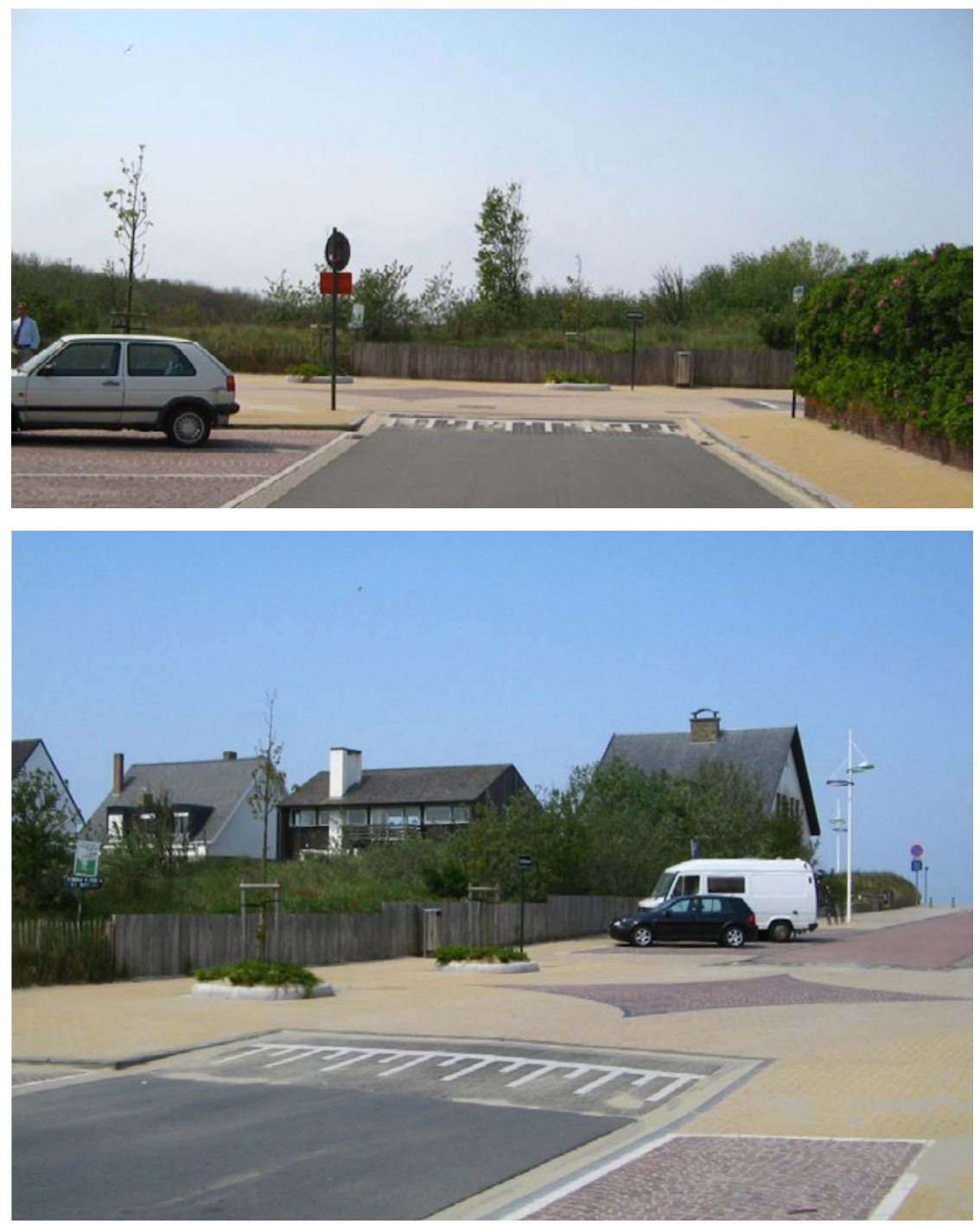

Ryc. 7. i 8. Zeebrugge, Belgia. Wyniesione skrzyżowanie rozwiązane w taki sposób, iż jego powierzchnia stanowi integralną całość z powierzchnią przyległych chodników. Źródło: fot. H. Trammer, 4 maja $2007 \mathrm{r}$.

Zeebrugge, Belgium. Tehe surface of the crossroad elevated to the level of the pavements and integrated with their surface. Source: phot. Hubert Trammer, May the $4^{\text {th }}, 2007$ 
a także faktycznie, ruch pieszych podporządkowany jest ruchowi pojazdów. Drugi rodzaj powierzchni to wyznaczone przejścia dla pieszych bez sygnalizacji świetlnej. Tam zgodnie z przepisami ruch pojazdów podporządkowany jest ruchowi pieszych. W rzeczywistości jednak postawa wielu kierowców sprawia, iż często jest tak tylko teoretycznie. Istotne znaczenie ma wielkość ruchu pieszego i samochodowego w poszczególnych tego typu miejscach. Aczkolwiek generalnie można zaobserwować poprawę postawy kierowców. Jednak daleko nam jeszcze do wielu krajów gdzie pozycja pieszych jest dużo mocniej osadzona w przepisach. Trzeci rodzaj z tych najczęściej spotykanych powierzchni to wyznaczone przejścia dla pieszych z sygnalizacją świetlną. W sytuacji czerwonego światła dla pieszych są to zgodnie z polskimi przepisami powierzchnie do wyłącznego ruchu pojazdów, zaś w sytuacji zielonego światła dla pieszych powierzchnie przeznaczone zasadniczo do ruchu pieszych, ale w niektórych sytuacjach z dopuszczeniem ruchu pojazdów. W przypadku przejść w obrębie skrzyżowań
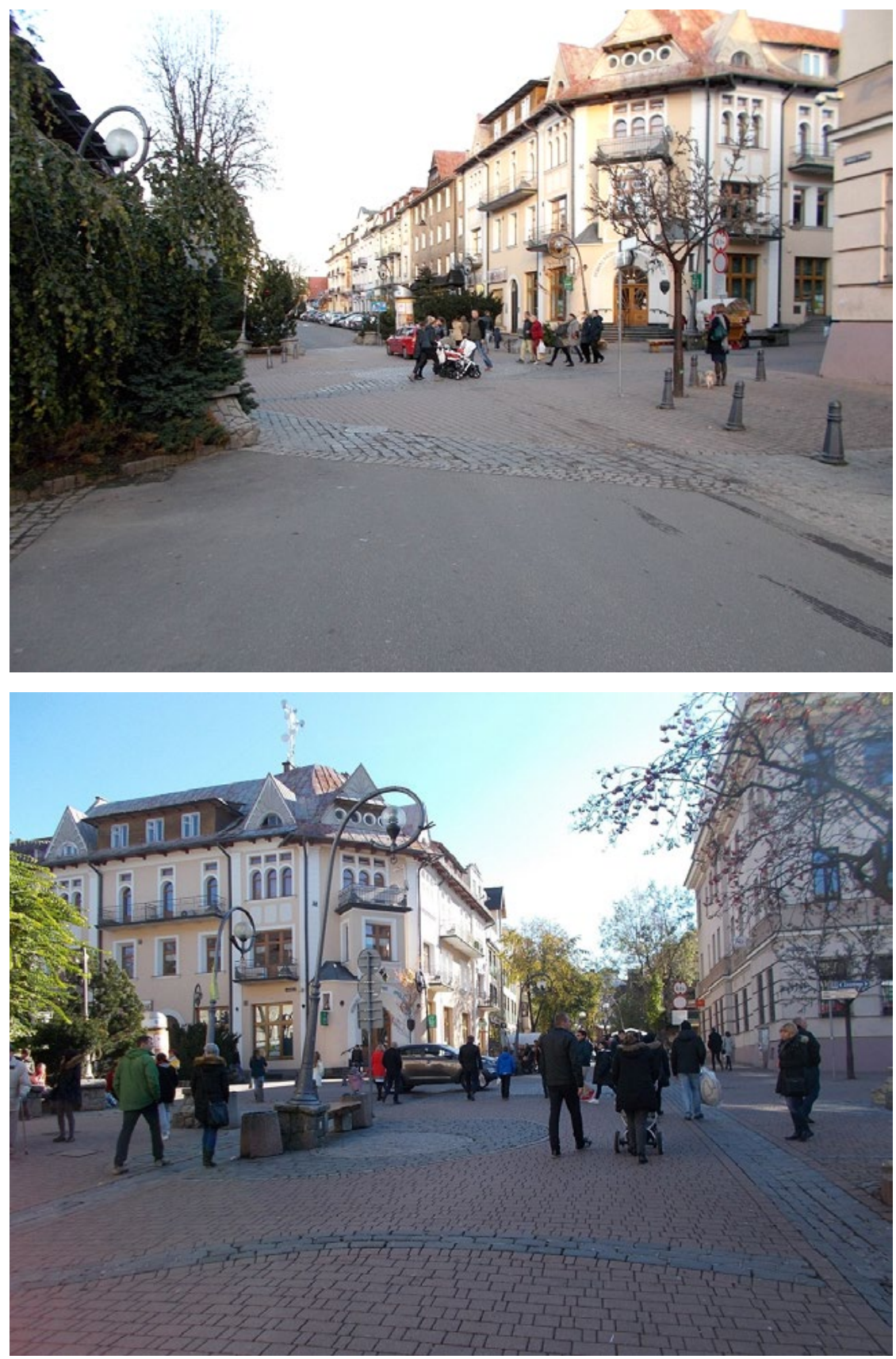

Ryc. 9. i 10. Centrum Zakopanego. Deptak Krupówki przerywa ciągłość prostopadłego ciągu ulic Kościuszki- Zaruskiego. Samochody przecinają deptak w miejscu w żaden sposób niewyróżnionym. Źródło: fot. H. Trammer, 23 października $2016 \mathrm{r}$.

Centre of the town of Zakopane. Krupówki promenade breaks the continuity of the perpendicular course of the Kościuszki and Zaruskiego streets. The cars cross the promenade in the place which is not marked in any way. Source: phot. Hubert Trammer, October the $23^{\text {rd }}, 2016$ 
pojazdy skręcające mogą przeciąć przejście dla pieszych, na których mają oni zielone światło, ale muszą ustąpić pierwszeństwa pieszym. Rzuca tu się w oczy nierówność stron. Równa sytuacja pieszych względem samochodów byłaby gdyby mogli oni przechodzić przez jezdnię na czerwonym świetle kiedy nie nadjeżdża żaden pojazd, lub gdyby samochody nie mogły przejeżdżać przez przejścia na których piesi mają zielone światło.

Rozwiązaniem często stosowanym, także w Polsce, które poprawia relacje pomiędzy ruchem pojazdów, a ruchem pieszych, zmniejszając dyskryminację tych ostatnich są wyniesione przejścia dla pieszych, a nawet całe skrzyżowania. W efekcie przejście dla pieszych, czy cała przestrzeń skrzyżowania staje się rodzajem wielkiego progu zwalniającego. Tworzy to w dużym stopniu równorzędną pozycję ruchu pieszego i ruchu samochodowego. Zarówno między chodnikami, jak i między odcinkami jezdni jest osobna powierzchnia, którą trzeba przekroczyć. Przy tym powierzchnia ta znajduje się na poziomie chodników (Ryc. 5 i 6).
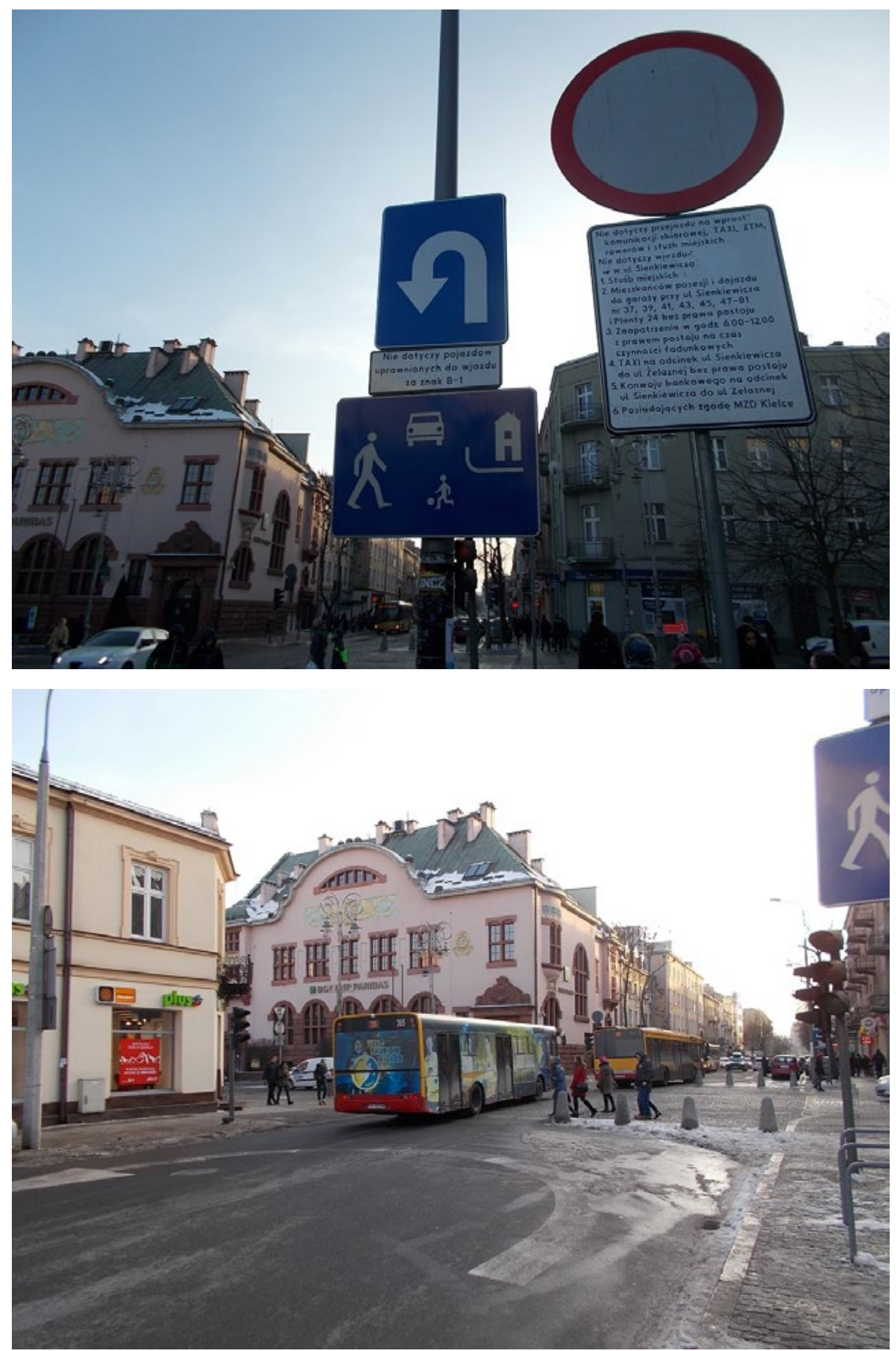

Ryc. 11. i 12. Kielce. Skrzyżowanie deptaku Sienkiewicza z ulicą Paderewskiego ukształtowane w sposób podporządkowany ruchowi pieszemu. Przejazd jest dopuszczony dla określonych grup pojazdów, w tym często kursujących autobusów komunikacji miejskiej. Źródło: fot. H. Trammer, 26 stycznia 2017 r.

Kielce. Crossroad of the Sienkiewicza promenade with Paderewskiego street shaped in the way which privileges the pedestrian traffic. Often running public busses and other selected groups of vehicles can cross the promenade. Source: phot. Hubert Trammer, January $26^{\text {th }}, 2017$ 
Rozwiązaniem, które ustawia ruch kołowy w pozycji podporządkowanej względem ruchu pieszego jest układ z przerwaniem ciągłości jezdni a bez przerywania ciągłości chodnika czy innego ciągu ruchu pieszego. Powszechna sytuacja przechodzenia pieszych przez jezdnię zostaje zastąpiona sytuacją przejeżdżania samochodów przez chodnik czy ciąg ruchu pieszego. (Ryc. 7 i 8). Kiedy chodnik jest wąski, bądź trasę przejazdu samochodów wydzielają słupki, sytuacja przypomina nieco wyniesione przejście dla pieszych. Zdarzają się jednak sytuacje organizacji i przestrzeni sprawiające, iż piesi mogą wręcz nie zauważyć, że przez chodnik, czy deptak wiedzie droga przejazdu pojazdów (Ryc. 9 i 10). Taka sytuacja występuje na przykład na zakopiańskim deptaku Krupówki. Mogłoby się wydawać, iż jest to sytuacja bardzo niebezpieczna i powodująca liczne wypadki. Okazuje się jednak, iż złożenie całej odpowiedzialność za bezpieczeństwo na kierowców pojazdów, wsparte rozwiązaniem nawierzchni sprawiającym, iż samochody wkraczają do domeny pieszych, mniej sprzyja wypadkom niż sytuacja, kiedy uważać muszą piesi, a nawet niż sytuacja, kiedy piesi na zielonym świetle przechodzą przez jezdnię. Istnieją także przykłady bezproblemowego przecinania deptaków przez ruch autobusów miejskich (Ryc. 11 i 12).

Zaprezentowany przykład przecinania deptaku, który stanowi ulica Sienkiewicza w Kielcach (Ryc. 11 i 12) pokazuje, iż ruch pieszy może bezpiecznie współistnieć bez wydzielania od bardzo intensywnego ruchu sporych pojazdów. Co więcej miejsca przecięcia deptaku z ulicą Paderewskiego jest także miejscem gdzie, ze względy na punktowe zwężenie tej drugiej, ruch pojazdów przecinających deptak musi odbywać się wahadłowo. Nie jest przy tym kierowany przez światła. Intuicyjnie mogłoby się wydawać, iż autobusy i inne pojazdy uprawnione do przejazdu są tam kierowane na czołowe zderzenie. Tymczasem organizacja ruchu powodująca, iż zapobieżenie wypadkowi między samochodami, wymaga zwiększonej uwagi, powoduje, iż jest bezpieczniej. Kierowcy, którzy muszą uważać, aby się nie zderzyć, uważają też bardziej na pieszych. Zachowaniu zwiększonej ostrożności sprzyja też zmiana nawierzchni.

Przedstawione wyżej różnorodne przykłady stanowią niewielką próbkę spośród niezliczonych miejsc gdzie zastosowane podobne rozwiązania, które funkcjonują i dobrze się sprawdzają. Jednak wciąż świadomość tego nie jest powszechna i wprowadzanie takich rozwiązań napotyka często opór. Nierzadko także wśród specjalistów od projektowania dróg i przestrzeni miejskiej. Przykładem były łódzkie woonerfy [Kubecka Zimny 2016]. Dlatego wiedza na ten temat wymaga szerokiego rozpowszechniania.

\section{Piśmiennictwo}

[1] Czarnecki B., Siemiński W., 2004, Kształtowanie bezpiecznej przestrzeni publicznej, Difin, Warszawa.

[2] Gehl J., 2009, Życie między budynkami. Użytkowanie przestrzeni publicznych, Wydawnictwo RAM, Kraków.

[3] Gehl J., 2014, Miasta dla ludzi, Wydawnictwo RAM, Kraków.

[4] Kubecka M. Zimny B. , 2016, Kierowca syty i pieszy caty, Magazyn Miasta 14 (2016) 133.

[5] mar, 2007, Warszawa: auto potracito pasażera... na stacji metra, portal gazeta.pl http://wiadomosci.gazeta.pl/wiadomosci/1,114873,3944269.html

\section{Paradox of the safety in the urban space}

\footnotetext{
Abstract: Coexistence of pedestrian traffic with the car traffic or tram traffic in many cases means better effects than their clear separation. It's the case in the field of the quality of staying in the city, but paradoxically also in the field of safety. In this publication are shown the examples of such solutions.
}

Keywords: safety, urban space, pedestrian traffic, car traffic, tram traffic, living street, pedestrian street 